\title{
The evolution of feminist literature in the Arab world
}

\begin{abstract}
In this article, we try to discuss the concept of the term "feminine literature" and the problems related to that in both Western and Arab worlds, with a historical overview of the evolution of Arab feminist literature from the pre-Islamic era to the present day. Besides that, we will relate to the difference between the writing of man and woman, as woman was distinguished by her own style as well as the issues she raises. However, despite the efforts, there has been a clear marginalization of woman's writing, and there was no clear definition of the term.
\end{abstract}

Keywords: feminist literature, the evolution of the modern feminist literature, woman literature

efore writing about the evolution of woman literature in the Arab world, it is

necessary to talk about and clarify the term and the issues related to it in this research, due to the fact that there are a number of expressions connected to this term in both the European and Arabic sciences. Some European writers use the term "The Woman Writer," as Gilbert and Gubar pointed out in their book ${ }^{1}$ while the Czech novelist Flakova referred to the term as "Modern Female Literature."”

${ }^{1}$ They pointed out that a woman-writer must do a search to understand and exceed the exaggerated images of women as an angel or beast as portrayed by the man-writer. S.M. Gelbert, S. Gubar, The Madwoman in the Attic, The Woman Writer and the Nineteenth Century Literary Imagination, Yaly University Press, New Haven and London 2000, second edition, pp. 16-17.

2 The writer described the role of the Czech women-writers in modern Czech literature. J. Flakova, Modern Czech Literature Written by Women, 2016, https://www.czechlit.cz/en/feature/ modern-czech-literature-written-by-women/. 
Women's critique appears as a term that attempts to study the ways in which literature has been formulated according to literary style. ${ }^{3}$ In his book on woman literary theory, Coward addressed the termswoman's narrative and woman's consciousness. ${ }^{4}$ In another source, the authors Warhol and Herndl pointed to the use of the terms women's critique, feminist literary theory, and feminist literature. ${ }^{5}$ Mary Eagleton defines women's literature as “the literature that seeks to uncover the special self-aspect of women away from those aspects that literature has long been concerned with. It is the literature that accurately expresses the special character of the female experience in isolation from the traditional concepts and embodies her experience in life. ${ }^{6}$

In the Arab world, feminist literature is not a new phenomenon of the contemporary Arab literature; rather it is like any other intellectual or literary phenomenon that has roots in the past. ${ }^{7}$ There were signs of feminist literature in the Ğāhiliyyaand the Islamic eras, but it was not that widespread. ${ }^{8}$ Women, in both eras, have excelled in both poetry and prose, and outshined in expressing their human feelings or political position by using the language with a sublime sense of taste. ${ }^{9}$ The status of Arab women has worsened since the late Umayyad era until the Ottoman era; yet by the end of the eighteenth century there were changes that assistedin changing the course of events ${ }^{10}$; the region witnessed many revolutions and confrontations and the beginning of the emergence of the Arab Renaissance. ${ }^{11}$ Feminist literature in the Arab world has been influenced by western feminist schools in addition to the historical and political transformations and changes throughout the Arab world

${ }^{3}$ When women's literary theory arose meaningfully in the woman movement that followed the Second World War. Among the most important of those who had the role in influencing the feminist critique are Ellen Moers, Carolyn Heilbrun, Sandra Gilbert, Susan Gubar, Annette Kolodny , Adrienne Rich , Elaine Showalter, Nina Baym, Alice Jardine, Catherine Stimpson, Gay-atriSpivak, Helene Cixous, LuceLrigaray, and Julia Kristiva, Merriam-Webster, Encyclopedia of Literature, Merriam-Webster Incorporated Publishers, Springfield, Massachusetts, 1995, p. 409.

${ }^{4}$ M. Eagleton, Feminist Literary Theory, third edition, Wiley-Blackwell, Malden, M.A, 2011, pp. 199-200, 203.

${ }^{5}$ R.R. Warhol, D.P. Herndl,Feminisms an Anthology of literary theory and criticism, Rutgers University Press, New Brunswick, New Jersey 1997, second edition, pp. x-xvii.

${ }^{6}$ A. 'Abbās, Faḍa'ātnasawiyyawa-mumārasāttī-l-adabwa-n-naqd, DārWā’illn-n-naŝrwat-tawazì', 'Amān 2013, p. 53.

7 The writer refers to Dīwān al-Hansā', which was published in 1888; the publisher was able to collect the lamentations of sixty women poets from the al-ㅍansā' era. Ğ. Kallās, Al-haraka an-nasawiyyafì așr an-nahḍa (1849-1928), Dār al-ğ̄il, Bayrūt 1996, p. 185.

${ }^{8}$ W. Sakākīnī, Insāf al-mar'a, Dimaŝq: Ṭllāsli-d-dirāsātwa-a-tarğamawa-n-naŝr, 1989, p. 95.

${ }^{9}$ There were many eloquent women in the Islamic era, but Mrs. A yŝā, the wife of the Prophet (pbuh), was considered the best. M. Șafūrī, Dirāsafī as-sard an-nasawī al- 'arabī alhadīt (1980-2007), Ḥayfā: Maktabatkulŝay’ (bi-dūntārīh ), p. 60.

${ }^{10}$ Ibidem, p. 90.

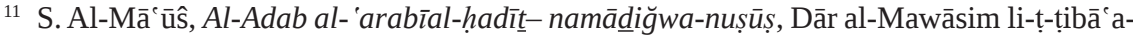
wa-n-naŝrwa-t-tawzīe , Bayrūt 1999, p. 25. 
that impacted the woman's status as well as changes in her perception.Although there are special characteristics of feminist literature, it is not separated from the social, cultural and political dialogue that surrounds it. ${ }^{12}$ Moreover, throughout historical moments, when the regions under colonialism were promoting intellectual, historical and cultural rise and counteracting colonialism, the Arab women's movement grew as part of the nation's antagonistic emotions. Foreign missions and delegations have contributed to the establishment of missionary and private schools, thus increasing the proportion of educated girls. ${ }^{13}$ This growth of feminist literature sustained until post-colonialism with varying strength from a stage to another to confront men and the society with its customs and traditions. ${ }^{14}$

"The emergence of the term 'feminist literature"” in the West, during the first half of the nineteenth century was controversial among critics. Part of the objection was based on the fact that this very literature is classified according to sexual principles rather than objective literary standards. On the other hand, some feminist critics perceived the term as a definition that fits women's literature because it is different in its experiences from men's literature.

In the Arab world, there was the same controversy over what happened in the western world. A number of Arab women writers objected to the term because it was a term created by men that degrades women's literature. However, Arab feminist criticism has recently played an active role in encouraging Arab female writers to accept the term due tothe advancement and excellence it dedicates to Arab women's literature and its effective role in this cultural heritage. ${ }^{15}$ On the other hand, there are critics who rejected the feminist literature, claiming that despite the similarities or differences between the writing of men and women, the definition of men's literature was not specified so that there will be female literature. ${ }^{16}$

Despite the controversy over the legality of dividing the literary output by gender classifications, somecritics point to the similarities between male and female writing on one hand, and differences on the other hand; the lack of compatibility in the topics between men and women writing is normal due to the differences between both parties. ${ }^{17}$ The similarity between men and women literary writing lies in terms of self-expression in a technical way; however most agree that there

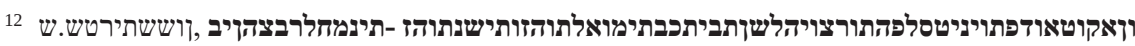

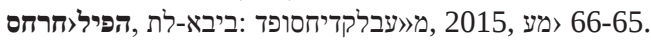

13 Ś. Al-Qiyādī, Ishām al-kātiba al- 'arabiyyafī'așr an-nahḍahattā 1914, falīta: Ś̉arikat ELGA, 1999, pp. 27-33.

${ }^{14}$ S.M. Quțub, F̌̃’adab al-mar'a, al-Qāhira: Aŝ-ŝarika al-mașriyya al-a ālamiyya li-n-naŝrLonğmān, 2000, p. 1.

${ }^{15}$ M. Șafūrī, Dirāsafĩ as-sard an-nasawī al- 'arabī al-ḥ adīṭ(1980-2007), Hayfā: maktabatKul-Š̉ay’, p. VI.

${ }^{16}$ S.M. Quțub, Fī’adab al- mar'a, p. 1.

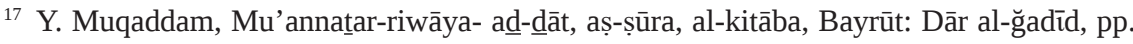
$18-19$. 
is a difference in writing between both of them, because of their different social, historical and life experiences, and other factors, which influence the styles and methods of artistic and creative expressionof both of them. ${ }^{18}$ Women's literature raises several issues including criticism of the social norms determined by men, ${ }^{19}$ claiming woman's freedom, and their openness to the Arab society which women address its problems and complexities and share its national concern. ${ }^{20}$ One of the salient phenomena of the modern Arab feminist narratives is the female writer's attention to the feminine self, making it her first issue; to make women the center of the text, after declaring man's failure to impose his authority and success on it. Women took their own position and increased their self-confidence. They reject the subordination by men, and resist masculine norms, in order to take primarily the resistance and presence of men, portraying men as a source of their troubles. After this stage of dealing with women's own issues, they move to the issues of the homeland and the nation until they end up examining the global ones. ${ }^{21}$ According to the studies of the modernist psychologists on literature and literary writers, they analyze the literary models as human experiences and deepen in the realm of the unconsciousness and human memories as being memories of popular legacies, tribal communities, or memories of mixed sexual and non-sexual tendencies. From all these memories and tendencies, writers bring them up in their literature, by organizing it in a way to influence the reader. "According to this psychological measure, the writer is a very imaginative and sensitive person; he responds largely to the external and internal influences he had in himself and inherited from his predecessors; a response that takes the form of feelings and emotions that he fits in a way to complement their relations on one hand and elements on the other hand, until it takes the special form in his literary impact." ${ }^{22}$ In his book "Women's Liberation," Amīn notes ${ }^{23}$ that every nation has its own norms and customs that suit its mentality. These norms change unconsciously according to "the authority of the

18 Ibidem, pp. 21.

19 S. M.Quțub, Fī 'adab al- mar'a, p. 1.

${ }^{20}$ I. Qādī, Ar-riwāya an-nasawiyyafỉbilādaŝ-ŝām- as-simāt an-nafsiyyawa-l-fanniyya - 19501985, Dimaŝq: al-ahālī li-țtṭibā'awa-n-naŝrwa-t-tawzīe, 1992, pp. 45-46.

${ }^{21}$ M. Șafūrī, Dirāsafī as-sard an-nasawī al- 'arabī al hadīț(1980-2007), Hayfā: maktabat Kul-Š̉ay', p. VI.

22 Ḍayf, Ś̉awqī, F̄̄ an-naqd al-adabī, al Qāhira: Dār al-Ma ārif fi mașr, 1966, at-tub`a a-tāniya, p. 52.

${ }^{23}$ QāsimAmīn (1863-1908) is an Arab narrator and writer of Kurdish origin who was born in the town of Tarrah from the suburbs of Cairo. After his arrival in Cairo and joining Azhar to study jurisprudence, Hadit and Sufism. He traveled to France to complement his education. He was influenced by what he saw there as women's freedom and her achieving high levels of education in schools and universities and her participation with men in public life. When he returned to Egypt in 1885, he worked in defense of women and called for that in his book entitled "Tahrīr al-mar'a" in 1899; he was criticized and insulted for that. He responded to his opponents in his second book, "al- mar'a al-ğadīda”, 1906. Also this book was faced with criticism. S. al-Sahạār, Mawsū 'ata' 'ām al- fikr al- 'arabī, al Qāhira: DārMașrli-țibā'a, Vol. 1, p. 54. 
territory, heredity and interferences, scientific inventions, literary schools, religious beliefs, political systems, and so on, and that each movement of the mind towards progress is inevitably followed by an impact that fits in customs and manners." ${ }^{24}$ One of the most prominent figures calling for the liberation of Arab women is Rifā'aat-Ṭahțāwī, ${ }^{25}$ who points out that the advancement of societies is based on women's progress. ${ }^{26}$ Many women's movements have emerged in the Arab world, which call for changing social forces and discrimination against women. Feminism has emerged as consciousness, science and a movement ${ }^{27}$ as well as a development of the feminist consciousness, including women's feminist movement in Egypt in the late $19^{\text {th }}$ century, led by the most prominent figures as Malak Ḥafnī Nāșif when she declared "women's demands in the Nation Party Club, and HudāSa arāwīin and her declaration with her companions the establishment of the Egyptian Women's Union, which includes political and social items. ${ }^{29}$ Women's associations were founded in Beirut. The first was the "Bākūrat Syria" in 1880 established by Maryam NimrMaqārios, in addition to the literary salons and later the publication of

${ }^{24}$ Q. Amīn, Taḥrīr al-mar'a, Kalimāt'Arabiyya li-tarğamawa-n-naŝr, al Qāhira 2011, p. 11.

${ }^{25}$ Rifā'aRāfi'aț-Ṭahțāwī (1801-1873), born in Țahțā, Upper Egypt. He joined al-Azhar and studied Arabic language, the principles of the Islamic religion and the Qur'an. He was sent by Muhammad'AlīPāsāa to Paris as a mission. He studied French and studied books with various topics and translated some of them into Arabic. He established the "Kindergarten Schools" Magazine and wrote many poems in love with the homeland. He supervised the editing of the "Al-waqā'i $i$ al-mișriyya” Magazine. Aț-Ṭahțāwī is one of the modern Egyptian thinkers. S. AlSahār, Mawsū 'ata 'lām al-fikr al- ‘arabī, al-Qāhira: DārMaṣrli-țibā’a, Vol. 1, p. 26.

${ }^{26}$ See Al-Hūury, 2001, at Șafūrī, Muhammad, Dirāsafĩ as-sard an-nasawī al- 'arabī al-ḥadīt (1980-2007), Ḥayfā: Maktabat Kul-Š̉ay’, bi-dūntārīh, p. 91.

${ }^{27}$ Feminism as a science and thought is "an in-depth study to differentiate between men and women in various spheres of life which is based on direct and indirect facts and an attempt to understand the causes of this differentiation, which feminists call the qualitative gap. Feminism as consciousness is: "the conscious awareness based on past facts, and this conscious realization shows that injustice and discrimination against women is not merely a historical coincidence, not a cultural or historical problem or an issue related only to poverty or ignorance. In spite of these reasons, discrimination is also linked to a complex package of direct and indirect factors, which solely fall on women yet the whole society suffers the consequences. H. Maḥmūd, Š̉. Țanțāwī, naẓra li-d-dirāsāt an-nasawiyya, A Guide, first publishing 2016, www.nazra.org.

${ }^{28}$ HudāS̆a rāwī (1879-1947), the daughter of Moḥammad Sulțān Paŝā, was born to a wealthy family but was unhappy with her status in the family and the distinction between her and her brother, in addition to the prohibition on educating women. After her father's death, she rushed to educate herself. When she was 13 , she was forced to marry 'AlīBīkaŝ-Š̉a rāwī, who was much older than her. At the time of the revolution in Egypt in 1919, she participated in the demonstrations, and was the first Egyptian woman to reveal her face. She was a supporter of QāsimAmīn when he published his book "Tahrīr al mar'a" and continued this way through the establishment of the Women's Union in 1923, the first union to advocate for women's rights. She had many contributions in this domain in addition to the establishment of a school to teach girls for free. For a quarter of a century, he represented the Egyptian women in the international conferences. S. Al-Saḥār, Mawsū 'ata 'lām al-fikr al- 'arabī, Alkāhira: DārMașrlil-țibā'a, b-dūntārīḥ, p. 88.

${ }^{29}$ H. Maḥmūd, Ś. Ṭanțāwī, naẓra lid-dirāsāt an-nasawiyya, dalīlirŝādy, al-iṣ̣ār al-’awwal 2016, www.nazra.org. 
magazines and newspapers. Women wrote using their real names such as the Wardā al-Yāziğ̄i and 'Ayŝāat-Taymūriyā,however there were many women writers who wrote under nicknames, until The Egyptian Association for the Advancement of Women began a campaign in 1908 calling for the right of women to use their real names. Women's writing was not limited to writing only in the newspapers and magazines. It invaded the space of the novel and consequently stories and novels were published quickly. Moreover, the geographical location of female writers was not limited to Egypt, Syria and Lebanon, rather it expanded over the years, from the 1930 s to the 1960s, to include most of the Arab countries. With the emergence of the literary breakthrough of the Renaissance, the feminist literature went along with this breakthrough out of the revival of science, translation and Arabization, poetry, journalism, story and novel. The feminist thought in the Renaissance worked in two ways, the theoretical which focused on the level of writing and the calling for education, and applicable, which targeted the level of establishing the associations and salons, creating newspapers and magazines and contributing to the establishment of schools." 30 "The feminization in the last quarter of the nineteenth century until the early twentieth century was a renaissance of journalism rather than a renaissance of writings." 31 In the last third of the twentieth century, the writing of women evolved and grew up, out of their experience and comprehensiveness of time and place. ${ }^{32}$ 'Abbās pointed out that the position of feminist activists has contributed to the promotion of awareness in the defense of women's rights and equal citizenship, including Nawālas-Sa dāwī, HudāS̆a arāwī, LaylāBa a albakī, Ğādaas-Sammān, LayānāBadr, In āmKağahğ̄̄ and others, as well as a group of poets and intellectuals. ${ }^{33}$ The contribution of woman to the academic scientific research to examine women's literature helped to "make a quantum leap in the thematic and technical aspects" in her literature. ${ }^{34}$ However, despite all the efforts, there has not been adequate focus on the writings of women from the pre-Islamic era to the present day. The writings of several women-writers have not been highlighted as with men. Moreover, there was also no single term referring to the product of the female literary work in both Arab and Western worlds, where the majority referred to the term as women's literature which can mean what women wrote or what was written about them. This research will present a new term, "Literary Writing by Women” which focuses on literature written by women.

${ }^{30}$ Ğ. Kallās, al-Haraka an-nasawiyyafĭ 'aṣr an-nahḍa (1849-1928), Dār al-Ğīl, Bayrūt 1996, pp. 188, 193.

${ }^{31}$ Ibidem, p. 188.

${ }^{32}$ Zāakiralil-mustaqbal - mawsū'at al-kātiba al-'arabiya (1873-1999), Lubnānwa- Sūriya, al-muğallad al-awwal, alqāhira: Mu’asasatNūr li-derāsātwa-'abḥāt al-mar’a, 2004, p. 17.

33 A. 'Abbās, Fī aț-taqāfawa-l-adab, Būznan: ma'had ad-derāsāt al-āsyawiyya, 2017, pp. 232-233.

${ }^{34}$ M. Șafūrī, Dirāsafĩ as-sard an-nasawī al- 'arabī al-ḥadīt(1980-2007), Ḥayfā: maktabatKul-Š̉ay’ (bi-dūntārīhn), p. 486. 


\section{Arabic Bibliography}

'Abbās A., Faḍa'ātNasawiyyawa-mumārasātfì l-adabwa-n-naqd, 'Amān: Dar Wā'il li-nnaŝrwa-t-tawazīe 2013.

'Abbās A., F̄̄ at-taqāfawa-l-adab, Būznan: ma`had ad-derāsāt al-āsyawiyya, 2017.

Al-Māeūŝ S., Al-Adab al- 'araby al-ḥadīt-namādiğwa-nușūș, Dāral-Mawāsim li-tibā'awan-naŝrwa-t-tawzīe , Bayrūt 1999.

Al-Qiyādī, Ś., Ishām al-kātiba al- 'arabiyafìa 'ṣr an-nahḍahattā 1914, Falītā:Š̉arikat ELGA, 1999.

Al-Saḥār, S., Mawsū 'ata 'lām al-fikr al- 'arabī, al-Qāhira: DārMiṣrli-t-tibāea, (bi-dūntārīh).

Amīn Q., Taḥrīr al-mar'a, Al-Qāhira: Kalimāt'Arabiyyali-tarğamawa-n-naŝr, 2011.

Ḍayf, S̉awqī, Fi-l-naqd al adabī, al-Qāhira: Dār al-Ma āriffīMișr, 1966, at-tub a a-tāniya.

Ḍayf, S̉awqy, Fī an-n-naqd al Adabī, Al-Qāhira: Dāral-Ma’ariffī mașr, 1966, at-tub a a-tāniya.

Kallās Ğ., Al-ḥaraka an-nasawiyyafí așr an-nahḍ a (1849-1928), Dār al-ğ̄il, Bayrūt 1996.

Maḥmūd H., Ṭanțāwī Ś., naẓra li-dirāsāt al-nasawiyya, dalīlirŝādy, al-iṣ̣̂̄r al-'awwal 2016, www.nazra.org.

Muqaddam Y., Mu'annatar-riwāya-ad-dāt, aș-șūra, al-kitāb, Dāral-ğadīd, Bayrūt 2005.

Qādī, I., Ar-riwāya an-nasawiyyafíbilādaŝ-ŝām as-simāt an-nafsiyawa-l-fanniyya - 19501985, al-ahālīli-țibāe a, wa-n-naŝrwa-t-tawzīe , Dimaŝq 1992.

Quțub, S.M., Fī'adab al-mar'a, al-Qāhira: Aŝ-ŝarika al-mașriyya al-a ālamiyya li-n-naŝrLonğmān, 2000.

Șafūrī, M., Dirāsa fi-s-sard an-nasawī al- 'arabī al-hadīt (1980-2007), Haî̃ā:maktabat Kul Ś̉ay', (b-dūntārīh).

Sakākīn̄̄ W., Insāf al-mar'a, Ṭllās li-dirāsātwa-t-tarğamawa-n-naŝr, Dimaŝq 1989.

\section{English Bibliography}

Flakova J., Modern Czech Literature Written by Women, 2016. https://www.czechlit.cz/en/ feature/modern-czech-literature-written-by-women/

Merriam-Webster K., Encyclopedia of Literature, Springfield, Massachusetts: Merriam-Webster Incorporated Publishers, 1995.

Eagleton M., Feminist Literary Theory, Wiley-Blackwell, Malden, M.A., 2011, third edition. Warhol R.R., Herndl D.P., Feminisms an Anthology of literary theory and criticism, Rutgers University Press, New Brunswick, New Jersey 1997, second edition.

\section{Hebrew Bibliography}

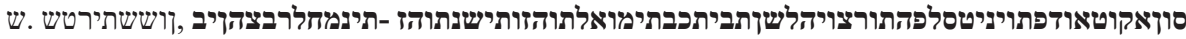

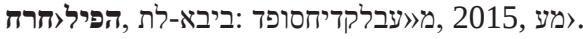


